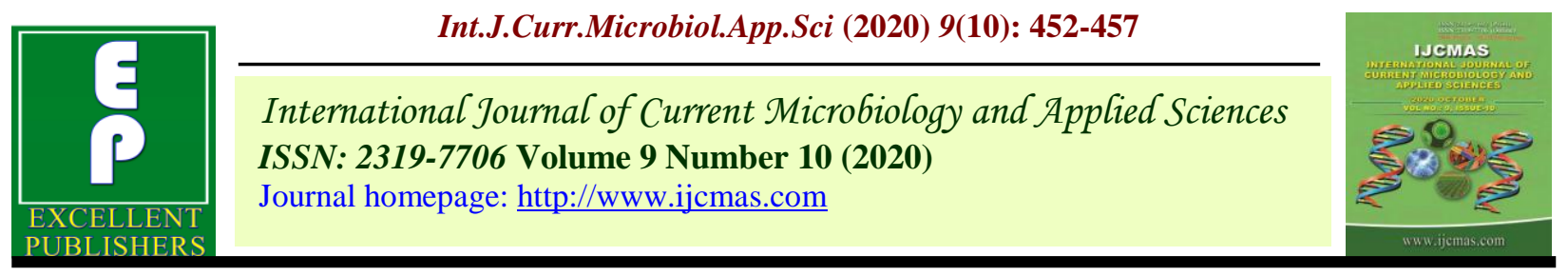

Original Research Article

https://doi.org/10.20546/ijcmas.2020.910.055

\title{
Studies on the Pattern of Changes in Fruiting behaviour of Ber (Ziziphus mauritiana Lamk.) Fruits during Growth and Development
}

\author{
Shiwanand Pandey* and Bhagwan Deen \\ Department of Horticulture, NDUA\&T, Kumarganj, Faizabad U.P., India \\ *Corresponding author
}

\section{A B S T R A C T}

\begin{tabular}{l} 
Key w or d s \\
Growth, \\
development, Peak, \\
Pickings, Semi-arid \\
\hline Article Info \\
\hline $\begin{array}{l}\text { Accepted: } \\
\text { 07 September } 2020 \\
\text { Available Online: } \\
\text { 10 October } 2020\end{array}$ \\
\hline
\end{tabular}

\section{Introduction}

Ber (Zizyphus mauritiana Lamk.) is an ancient fruit tree of India and China. In fact it was one of the prominent fruits on which sages in ancient India lived during Vedic ages. There is a reference to ber in "Yajurved", written not later than 1000 B.C. Ber (Ziziphus mauritiana Lamk.) is also known as Chinese date, Chinee/Chinkee apple, jujube, Indian plum, Regi pandu, Indian jujube and masau, belongs to the family Rhamnaceae and genus Zizyphus. It is a tetraploid $(2 n=48)$ in nature. It is grown in countries like Iran, Syria, Australia, USA, France and certain parts of Italy, Spain and Africa. Precisely it is seen to be growing under tropical and sub-tropical as well as Mediterranean regions of the world. It grows even on the marginal soil and various kinds of waste land situation such as sodic saline soil, ravines, arid, semi-arid region including plated area of Bundelkhand and South India. Regarding its distribution it grows most widely in Punjab plains, U.P., Haryana, Rajasthan, M.P., Bihar, Maharashtra, Assam, A.P., Tamil Nadu and West Bengal. In U.P. ber orchards are found around Varanasi, Aligarh, Saharanpur, Faizabad, Agra and Raibareilly districts. However, scattered planting is common in plains. It is hardy and flourishes well under little care in wide range of soils and climatic conditions. The ripe ber fruits have high nutritive values and 
conventionally it is considered a "Poor man's fruit" The ber fruit is richer than apple in protein, phosphorus, calcium and Vitamin ' $\mathrm{C}$ ' (Bakshi and Singh, 1974) and one hundred gram of edible ber fruit contains moisture (85.9\%), protein $(0.8 \mathrm{~g})$, fat $(0.1 \mathrm{~g})$, carbohydrate $(12.88 \%)$, calcium $(0.03 \mathrm{~g})$, phosphorus $(0.03 \mathrm{~g})$, iron $(0.8 \mathrm{~g})$, carotene $(70$ IU) and vitamin ' $\mathrm{C}$ ' (50-100mg). Also suggested in detailed pharmacological investigation of $Z$. jujube, various Ayurvedic and yunani medicines containing ber extract are said to be a blood purifier and also help in digestion.

The powder and decoction prepared from the roots are effective in case of fever, ulcers and old wounds. The stem bark is considered to be a remedy for diarrhea. The medicinal values of various parts of the tree and fruits of Ziziphus spp. are many and yet not fully exploited (Sin ko, 1976). The maturity plays an important role in quality and shelf life of ber fruit. The studies on changes during growth and development are essential requirement to determine the maturity, harvesting time and method. The present investigations were therefore, aimed to generate basic information on the namely fruiting behaviour of ber.

\section{Materials and Methods}

The present investigation was carried out at Main Experiment Station of the Department of Horticulture, Narendra Deva University of Agriculture \& Technology, Narendra Nagar, Kumarganj, Faizabad 224229 (U.P.) India during the years 2016-17. The experiment was conducted on 24 years old uniform vigorous ber trees (Nrendra Ber Selection-1) which received uniform cultural operation throughout the experimental period. The details of the materials used, the trial was laid out in a randomized block design having six treatments with four replications.
The number of flower on the day of observation was recorded at 7 day interval and percent flowering was calculated against total number of flower on the shoot. The number of fruit set against number of flower recorded in previous observation was counted and percent was calculated against total number fruit set on the tagged shoot. The total number of fruit retained fruits on observation day was subtracted from fruit set to get number of fruit drop on observation day. The fruit drop was calculated against total fruit drop from the tagged shoot. Fruit retention found to be recorded on the of observation and percent fruit retention was calculated against total number of fruit retained on the tagged shoot up to maturity. The yield per tree was recorded at the time of harvesting by weighing of fruit and expressed in $\mathrm{kg} /$ tree.

\section{Results and Discussion}

The observation on the following attributes was started to record since 18.09.2016 when axillary flower buds appear first time. Flowering and fruiting attributes the flowers were initiated first fourth night of September. The total duration of flowering was recorded to 56 days and the peak period was between 7 and 35 days from the start of flowering that indicating 28 days period of peak flowering in ber cv. Narendra Ber Selection-1.The total duration of flowering varied from 68 to 94 days (Babu and Kumar, 1998) and 57 to 75 days (Dhaliwal and Bal, 1998) depending upon cultivar. Total flowering duration of cultivar Gola was recorded as $71+5.62$ days and cultivar Seb was $68+4.49$ days (Garhwal, 1997). Pareek (2009) observed shortest duration of flowering in cultivar Tikadi (47 days) and longest in cultivar Umran (71 days) similar result also observed by (Singh et al., 1970) at Hissar, in 'Banarsi Karaka' which flowered from September to November, the total flowers, 2 per cent 
appeared in September,83 per cent in October and the rest 15 per cent in November. The fruit drop started after fruit set and continued up till harvesting of the drop was at peak during initial period of fruits growth and development and fruit drop percent showed decreasing trend as fruits proceeded to maturity. The present findings are also in accordance to the observations recorded by Teaotia and Chauhan (1964) observed that the peak period of drop in Banarsi Pewandi and Thornless fell respectively during October 14 and November 25 and November 11 and December 9 whereas no such peak occurred in 'Banarsi Karaka'. They further observed that the highest drop of 94.8 per cent was recorded in Banarsi Pewandi having highest initial set and the lowest in 'Banarsi Karaka' having lowest initial set (Fig. 1-4 and Table 1).

Table.1 Fruiting behaviour of ber

\begin{tabular}{|c|c|c|c|c|c|c|}
\hline \multicolumn{2}{|c|}{$\begin{array}{l}\text { Interval } \\
\text { (Days) }\end{array}$} & $\begin{array}{l}\text { Flowering } \\
(\%)\end{array}$ & $\begin{array}{l}\text { Fruit setting } \\
(\%)\end{array}$ & $\begin{array}{l}\text { Fruit drops } \\
(\%)\end{array}$ & $\begin{array}{l}\text { Fruit } \\
\text { retention } \\
(\%)\end{array}$ & Yield kg /plant \\
\hline \multirow{3}{*}{$\begin{array}{l}1 \\
7 \\
14\end{array}$} & \multirow{3}{*}{$\begin{array}{l}\text { September } \\
\text { second fourth } \\
\text { Night }\end{array}$} & 7.55 & 0.00 & 0.00 & 0.00 & - \\
\hline & & 11.34 & 14.43 & 0.00 & 0.00 & - \\
\hline & & 15.75 & 18.18 & 9.45 & 28.93 & - \\
\hline \multirow{4}{*}{$\begin{array}{l}21 \\
28 \\
35 \\
42\end{array}$} & \multirow[t]{4}{*}{ October } & 14.57 & 13.89 & 11.13 & 30.62 & - \\
\hline & & 13.57 & 11.59 & 12.32 & 35.66 & - \\
\hline & & 10.66 & 11.01 & 14.33 & 41.76 & - \\
\hline & & 9.29 & 9.22 & 10.22 & 46.25 & - \\
\hline \multirow{4}{*}{$\begin{array}{l}49 \\
56 \\
63 \\
70\end{array}$} & \multirow[t]{4}{*}{ November } & 9.19 & 7.79 & 3.29 & 47.11 & - \\
\hline & & 8.08 & 6.14 & 3.25 & 47.99 & - \\
\hline & & - & 3.29 & 3.25 & 48.06 & - \\
\hline & & - & 2.72 & 2.24 & 46.89 & - \\
\hline \multirow{4}{*}{$\begin{array}{l}77 \\
84 \\
91 \\
98\end{array}$} & \multirow[t]{4}{*}{ December } & - & 1.74 & 3.25 & 45.23 & - \\
\hline & & -- & - & 3.25 & 45.18 & - \\
\hline & & - & - & 2.75 & 44.04 & - \\
\hline & & - & - & 2.47 & 43.23 & - \\
\hline \multirow{4}{*}{$\begin{array}{l}105 \\
112 \\
119 \\
126\end{array}$} & \multirow[t]{4}{*}{ January } & - & - & 2.51 & 39.83 & - \\
\hline & & - & - & 2.36 & 32.26 & - \\
\hline & & - & - & 2.34 & 29.45 & - \\
\hline & & - & - & 2.09 & 27.84 & - \\
\hline \multirow{4}{*}{$\begin{array}{l}133 \\
140 \\
147 \\
154\end{array}$} & \multirow{4}{*}{ February } & - & - & 2.07 & 27.54 & - \\
\hline & & - & - & 2.05 & 25.81 & - \\
\hline & & - & - & 1.82 & 22.11 & 18.55 \\
\hline & & - & - & 1.17 & 19.35 & 29.82 \\
\hline \multirow{3}{*}{$\begin{array}{l}161 \\
168\end{array}$} & \multirow[t]{2}{*}{ March } & - & - & 1.07 & 17.95 & 40.36 \\
\hline & & - & - & 0.82 & 15.25 & 31.62 \\
\hline & & 0.84 & 0.64 & 0.49 & 2.78 & 2.41 \\
\hline \multicolumn{2}{|r|}{ CD at $5 \%$} & 2.44 & 1.85 & 1.38 & 7.84 & 7.29 \\
\hline
\end{tabular}


Fig.1

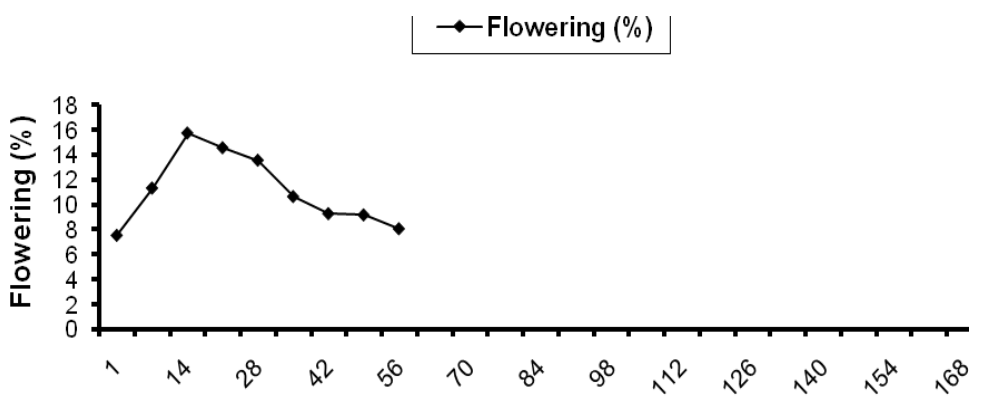

Interval(Days)

Changes in flowering during growth and development of ber fruit

Fig.2

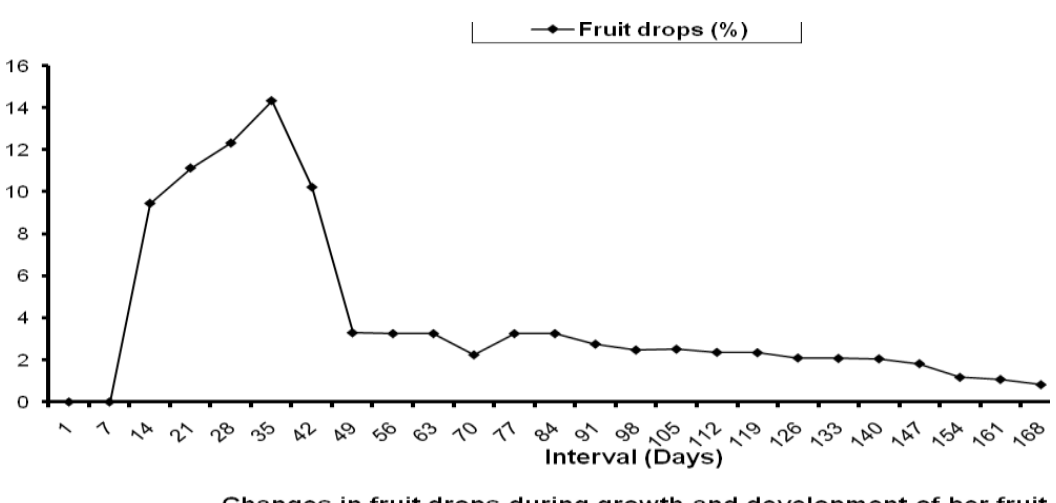

Fig.3

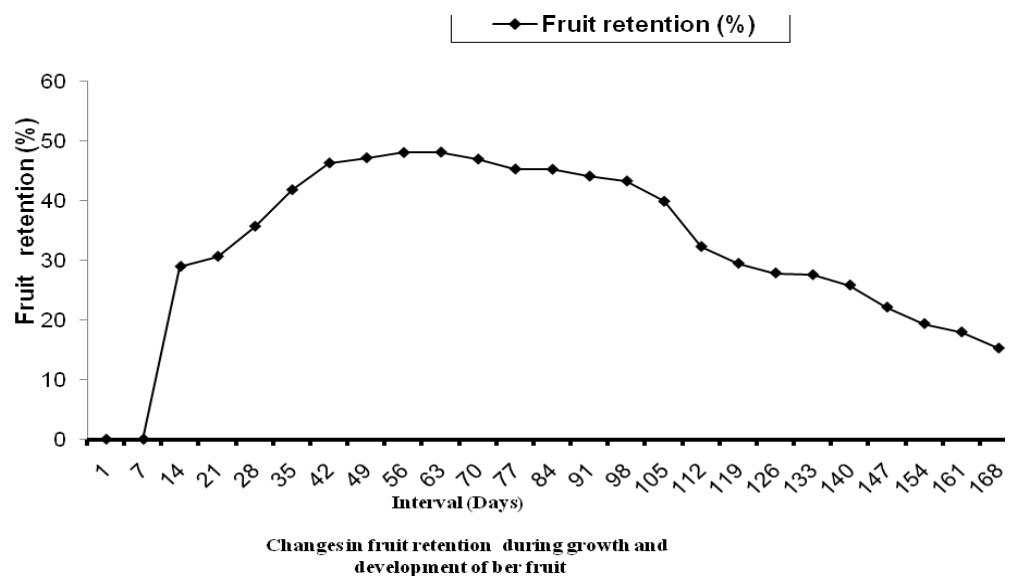


Fig.4

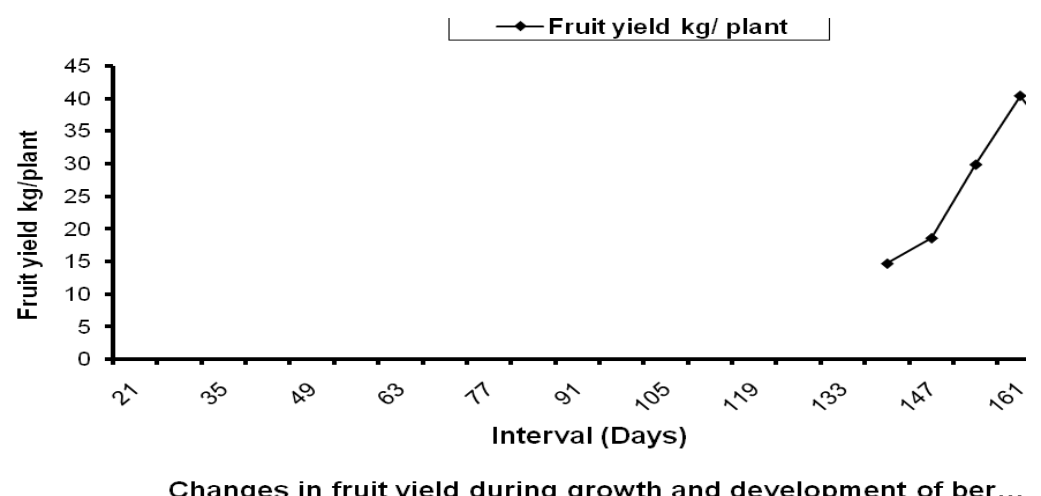

The maximum fruit retention $(48.06 \%)$ was in third week of November (63 days after flowering) and minimum $(15.25 \%)$ in first forth night of March (168 days after flowering) were recorded. Initial stage of during fruits growth and development the fruit retention was recorded to be higher in compression to latter stage. The present finding is in conformity with observations recorded by Sharma et al., (1990) evaluated Banarasi Karaka, Ponda, Ilaichi, Gola and Tikdi cultivars of ber. They reported that the peak period of flowering and fruit set was September-October for all cultivars. The earliest flowering (11 September) and initiation of fruit set (21 September) were observed in Tikdi, which had the shortest duration of flowering (47 days) and fruit set (36 days). The maximum fruit set $(28 \%)$ and fruit retention $(20 \%)$ was observed in Tikdi. The longest duration of flowering (61 days) and fruit set (50 days) and the lowest fruit retention $(4 \%)$ were observed in Illaichi. The complete harvesting required total five pickings which might be due to flowering and fruit setting in different time on the current season continuous growth of the ber plant. Rahman et al., (2006-2007) reported 41.00 $\mathrm{kg} / \mathrm{plant}$ in cv. ZM-054. The different in yield as compared to literature is obvious due to cultivar agro-climatic condition and cultural practice.
It can be concluded from the experiment conducted to study the fruiting behavior of ber plant. The number of flower and flowering percentage increased continuously from after fourth night of September to third week of September then decreased till the second week of November the flowering was stopped. The fruit setting took place between third week of September to first week of December and the peak period for fruit setting was second week of September to third week of October the fruit setting was continuously decreased after last week of September. The fruit drop percentage was high at initial stage of fruit setting means first week of October to third week of October then continuously decreased till harvesting means second week of march. The fruit retention percentage was found less at initial and stage last stage of fruit growth and development, fruit retention percentage was high at second and third week of November and at harvesting time was found less in second week of March.

\section{References}

Babu, R.H., and Kumar, P.S. (1998). FLoral biology of ber Haryana J. Hort Sci., 17, 24-27.

Bakhshi, J.C. and Singh, P. (1974). The ber a good choice for semi-arid and marginal soils. Indian Hort., 19: 27-30.

Dhaliwal, J.S. and Bal, J.S. (1998). Ber in 
fruit, tropical sub tropical (end. T.K. Boss; S.K. Mitra; and D.sanyal ), Naya udyog Calcutta 2:681-692.

Garhwal, O.P. (1997). Varietial evaluation of ber fruits M.Sc. Thesis, Rajasthan Agric. Univ., Bikaner, India.

Pareek S., and Dhaka RS. (2009). Association analysis for quality attributes in ber. Ind. J. Arid Hort., 3:77-80.

Rahman, M. M. S., Hoque, M. A. (2006-07). Evaluation of ber germplasm. Annual Report, Pomology Division, HRC.

Sharma, V.P., Raja P.V., and V.N. Kore. (1990). Flowering, fruit set and fruit drop in some Ber (Ziziphus mauritiana Lamk.) varieties. Annual Agriculture Reserch Instnstitute, New Delhi,
India. 11: 14-20.

Singh, D., Bakhshi, J. C., and Singh, K. (1970). Flowering and fruiting behavior of ber, variety Banarsi Karaka (Zizyphus mauritiana Lamk.). Punjab hort. J. 10:21-28.

Sinko, L. T., Kucherova, T. P., and Vilde, E.I. (1976). ber in fruit, tropical sub tropical (end. T.K.Boss; S.K. Mitra; and D.sanyal 102:56-64.

Teaotia, S. S. and Chauhan R. S. (1964). Flowering pollination fruit set and fruit drop studies in ber (Zizyphus mauritiana Lamk.) floral biology. Punjab Horticultural Journal.3: 60-70.

\section{How to cite this article:}

Shiwanand Pandey and Bhagwan Deen. 2020. Studies on the Pattern of Changes in Fruiting behaviour of Ber (Ziziphus mauritiana Lamk.) Fruits during Growth and Development. Int.J.Curr.Microbiol.App.Sci. 9(10): 452-457. doi: https://doi.org/10.20546/ijcmas.2020.910.055 